\title{
Ideas of technical and economic study programs in higher education
}

\author{
Bondareva Irina ${ }^{1}$ and Tomlain Juraj ${ }^{1 \mathrm{a}}$ \\ ${ }^{1}$ Management Institute of the Slovak University of Technology, Vazovova 5, 81243 Bratislava, \\ Slovakia
}

\begin{abstract}
Higher education has to adapt to the market principles in postsocialistic countries after the year 1989. The training of graduates should constantly reflect on the business environment, where the graduates are coming after university study. A lot of them do not want to obtain only detailed knowledge from technical subjects as electrotechnics, chemistry, informatics, etc., but they require training (lectures, exercises, workshops) in the field of economics, management of small and medium enterprises, marketing, and finances. The study combination of an entrepreneurial focus on the technical / technological universities brings high-qualified high-engaged and flexible young people for immediately changing market. The real experience and results with this type of the study in the Slovak university of technology Bratislava - Institute of management are discussed in the conclusion of the paper.
\end{abstract}

Keywords: technical education; economical education; higher education; entrepreneurial focus

\section{Introduction}

The process of globalization dictates its harsh conditions for survival, existence and dominant position, which brings corrections into the dynamics of competitiveness and economic development of the Slovak Republic. The economic recession fundamentally changes the parameters of economic development sustainability of Slovakia. According to the World Economic Forum [5], the innovation potential is one of the most important pillars of the further economic development and growth of competitiveness of Slovakia. Fundamental opportunity for economic growth of Slovakia is the change in industrial structure of the economy towards a higher share of knowledge-intensive business services, KIBS.

An important factor of the innovation potential of the country is the level of university education system in the country. Innovative direction of development of Slovakia and its regions brings new demands on the quality of human capital, which should guarantee the

\footnotetext{
${ }^{a}$ Corresponding author: juraj.tomlain@stuba.sk
} 
capability and readiness of specialists to solve tasks of the innovation process. Shaping of knowledge society increases the dependence of economic and social progress on the level and quality of vocational training, especially of young people. The requirements for the level and quality of human capital development, which is presented by the knowledge economy, partly defines tasks of the education system. In Slovakia, as well as in other EU countries, education is included in country priorities. The level and quality of education and professional training are included in the main factors of the incoming development of the knowledge economy.

\section{Current situation}

Higher level of education of workers and personnel is nowadays practically essential for economies that want to remain among leading countries, or want to move on. It is particularly the ability of workers and managers to flexibly perform more complex tasks, to understand more complicated work processes and make more effective decisions.

Comparison of the value of country competitiveness pillar "Higher education and training" of Slovakia with the countries of the Visegrád Group (V4) is shown in Figure 1 and shows that Slovakia is lagging in this area.

Individual components of this pillar consist of:

Higher education and training (5th pillar):

A. Quantity of education

5.01 Secondary education enrollment, gross $\%$

5.02 Tertiary education enrollment, gross $\%$

B. Quality of education

5.03 Quality of the education system

5.04 Quality of math and science education

5.05 Quality of management schools

5.06 Internet access in schools

C. On-the-job training

5.07 Availability of research and training services

5.08 Extent of staff training

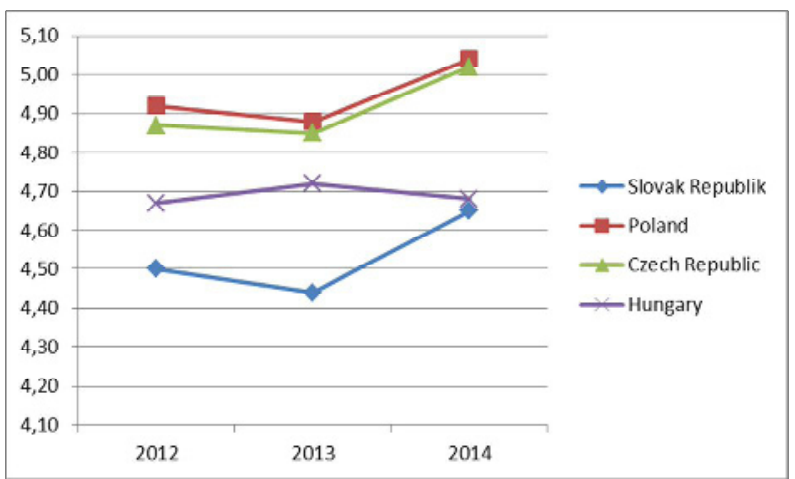

Fig. 1. Comparison of the value of pillar "Higher education and training" of Slovakia with the countries of the Visegrád Group (V4) (Authors, on basis of WEF data [5]) 
In relation to the above, the Slovak government pays great attention to education, as reflected in strategic documents on development of Slovakia, including document Innovation Strategy of Slovakia for 2014-2020, which is based on the principles of strategic document Europe 2020.

The document states that Slovakia has demonstrable potential for innovation, but it is necessary to stimulate and support its growth. The strategy of innovative development of Slovakia until 2020 states objectives, the achievement of which will determine the place of Slovakia in the global economic space. A special place among the factors ensuring effective implementation of strategic objectives and tasks is occupied by the level and quality of education of the country population. The status of meeting the main objectives of strategy Europe 2020 in the Slovak Republic is shown in Table 1.

Table 1. Objectives of the innovation Strategy of Slovakia for 2014-2020 in the area of research and education (Authors, based on the Innovation Strategy of Slovakia for 2014-2020)

\begin{tabular}{lcc}
\hline \multicolumn{1}{c}{$\begin{array}{c}\text { The main objectives of the Europe } \\
\text { 2020 strategy }\end{array}$} & $\begin{array}{c}\text { Current situation } \\
\text { in Slovakia } \\
\text { (year 2013) }\end{array}$ & $\begin{array}{c}\text { National objective } \\
\text { in the National Reform } \\
\text { Programme up to 2020 }\end{array}$ \\
\hline $\begin{array}{l}\text { At least 40\% of population aged 30-34 } \\
\text { having completed university or } \\
\text { equivalent education }\end{array}$ & $26.9 \%$ & $40 \%$ \\
\hline $\begin{array}{l}\text { Invest 3\% of GDP into research and } \\
\text { development }\end{array}$ & $0.83 \%$ & $1 \%$ \\
\hline
\end{tabular}

The data in Table 1 show that there are significant differences between the current situation and the national objectives for 2020 in the area of university education of population. Lagging of Slovakia can also be observed in the population aged 30-34 with a university degree, compared to the average of EU28. Also, the amount of investment into education and training in Slovakia (3.8\% of GDP) is lagging compared to the average of EU28 (5.3\%). The average annual expenditure per student is $€ 6,147$, which is $35 \%$ less than the average of EU28 (€ 9,475) [1,2].

As some authors say "There are many political declarations emphasising the importance of science, research and innovation, but there is much less political will to financially support the area" [3].

Countries with developed system of university education are characterized by high indicators of cost per student, mostly university graduates, among which technical and engineering specializations are prevalent, as well as a high mobility of students. The most competitive university education systems use new technologies in the organization of teaching processes, introduce innovative methods of lecturing and educate highly qualified specialists who can be used in the labour market, virtually worldwide. The effective combination of experience and traditions, as well as early utilization of innovation in the university education system allow a selected group to become an exemplary group.

To evaluate the innovation development of the university education system, it is necessary to use a high number of indicators that include qualitative and quantitative indicators.

In Figure 2, the authors compare some basic parameters of the university education system in Slovakia and Finland, which, according to WEF, has the best evaluated pillar of country competitiveness "Higher education and training", also when compared with the average of EU28. For comparison purposes, the average value of EU28 is marked as $100 \%$.

However, not only the level of investment into education is important, but also the structure of the entire university education system. In Slovakia, disproportion can be 
observed between the young people with humanities and social science education in comparison with technical and natural science education. Virtually all private schools prepare only specialists in the area of humanities and social sciences.

The analysis also shows that curricula are often far behind the requirements of the real life needs, as evidenced by the fact that some foreign investors are considering leaving the Slovak market due to lack of technically trained staff, or they invite foreign specialists to Slovakia, regardless of the high level of youth unemployment in Slovakia. The problem also is that in Slovakia in comparison with OECD countries, according to OECD data, there is significantly lower proportion of people aged 25-64 who participate in lifelong learning, which leads to obsolescence of knowledge [4].

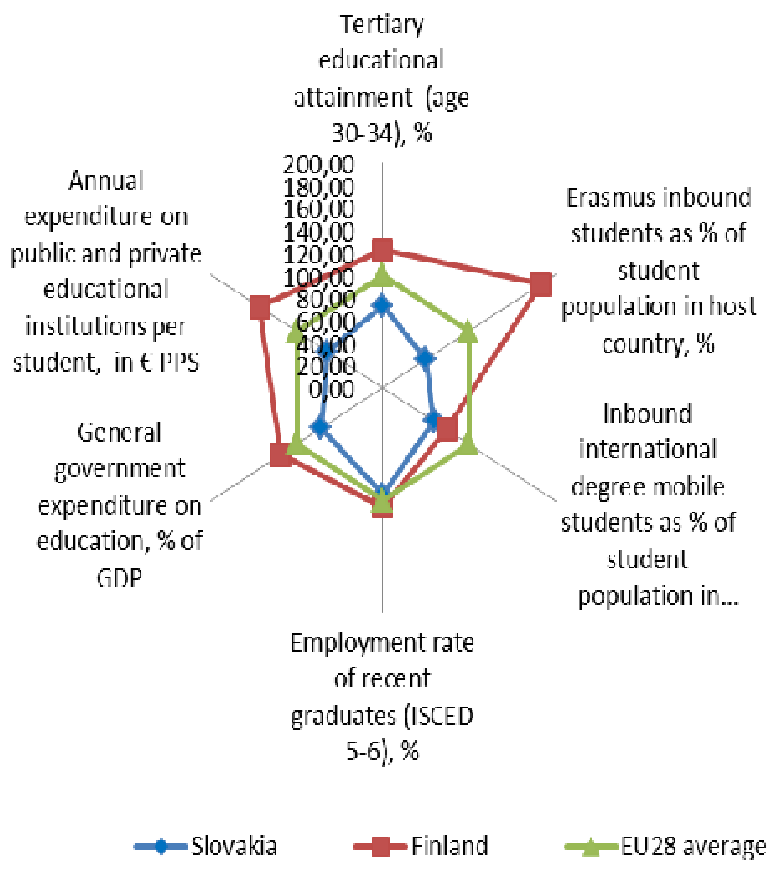

Fig. 2. Comparison of basic parameters of university education system of Slovakia and Finland with the average of EU28(Authors)

Due to the high number of private universities in Slovakia, there is often significant depreciation of the level of the education process. Effortless way of obtaining a diploma attracts a significant proportion of the young population of Slovakia to study at private universities. However, the issue of employability of graduates, the issue of supply and demand according to specific study programs as well as the issue of quality and comparability of university studies come into focus. The quality and comparability in Europe is dealt with by the Bologna process, which analyses in detail and recommends activities for a number of areas, but especially for the system of easily comparable 
academic degrees and diplomas. However, there is a much more fundamental and more acute problem regarding employment or unemployment of graduates of almost forty Slovak universities and colleges. Here the fundamental question arises, whether the study fields so widely offered and attended will give the graduates education required and necessary for labour market.

Quality and reputation are maintained in the long term mainly by established schools with a long tradition and high ranking of prepared specialists. One such university is the Slovak Technical University (STU) in Bratislava. In this article we want to highlight the experience of sectional (technical - economic - managerial) education offered at Slovak Technical University in Bratislava by its Institute of Management.

\section{Concurrent study of subjects with economics focus at the Faculty of Electrical Engineering and Information Technology}

Students both degrees (Bachelor, Master) may enroll for this kind of concurrent study. It is a complementary study, which is nominally scheduled for 2 semesters. However, the duration and schedule (in accordance with the credit system of education) is chosen by the student.

The following table (elaborated according to the current curriculum of the faculty) shows the scopes and credits for individual subjects.

Table 2. The first semester

\begin{tabular}{lccc}
\hline The subject & $\begin{array}{c}\text { Number of } \\
\text { lectures per } \\
\text { week }\end{array}$ & $\begin{array}{c}\text { Number of } \\
\text { seminars(workshops) } \\
\text { per week }\end{array}$ & Credits(ECTS) \\
\hline $\begin{array}{l}\text { Business } \\
\text { Administration }\end{array}$ & 2 & 2 & 5 \\
$\begin{array}{l}\text { Entrepreneurial } \\
\text { Management }\end{array}$ & 3 & 2 & 6 \\
Marketing & 3 & 2 & 6 \\
Semestral project I. & 0 & 6 & 0 \\
\hline
\end{tabular}

Table 3. The second semester

\begin{tabular}{lccc}
\hline \multicolumn{1}{c}{ The subject } & $\begin{array}{c}\text { Number of } \\
\text { lectures per } \\
\text { week }\end{array}$ & $\begin{array}{c}\text { Number of } \\
\text { seminars(workshops) } \\
\text { per week }\end{array}$ & Credits(ECTS) \\
\hline Accounting & 2 & 3 & 6 \\
Financial management & 2 & 2 & 5 \\
Semestral project II. (final thesis) & 0 & 6 & 6 \\
\hline
\end{tabular}

For successful completion of the study, the student must obtain 34 credits and defend the final written work.

\section{Combined engineering study at the faculty of chemical and food technology}

It is an accredited engineering curriculum named "Management of technological processes in chemical and food industries". It consists of 4 semesters and the following table (elaborated according to the current curriculum of the faculty) shows the scopes and credits for individual economic subjects. 
Table 4. The first semester

\begin{tabular}{lccc}
\hline \multicolumn{1}{c}{ The subject } & $\begin{array}{c}\text { Number of } \\
\text { lectures per } \\
\text { week }\end{array}$ & $\begin{array}{c}\text { Number of } \\
\text { seminars(workshops) } \\
\text { per week }\end{array}$ & Credits(ECTS) \\
\hline Enterprise economy & 2 & 2 & 7 \\
Budgeting in technologies & 2 & 2 & 6 \\
Strategic decision making in technology & 3 & 2 & 7 \\
Basic of logistics (optional) & 2 & 1 & 4 \\
\hline
\end{tabular}

Table 5. The second semester

\begin{tabular}{lccc}
\hline \multicolumn{1}{c}{ The subject } & $\begin{array}{c}\text { Number of } \\
\text { lectures per } \\
\text { week }\end{array}$ & $\begin{array}{c}\text { Number of } \\
\text { seminars(workshops) } \\
\text { per week }\end{array}$ & Credits(ECTS) \\
\hline Financial market & 2 & 2 & 5 \\
Marketing & 3 & 2 & 6 \\
Investment development & 1 & 1 & 3 \\
Mathematic models in decision-making & 2 & 2 & 5 \\
Innovation and change management & 1 & 1 & 3 \\
Management of the production process & 2 & 2 & 3 \\
Corporate Finances (optional) & 2 & 2 & 5 \\
Accounting (optional) & 2 & 1 & 4 \\
\hline
\end{tabular}

Table 6. The third semester

\begin{tabular}{lccc}
\hline \multicolumn{1}{c}{ The subject } & $\begin{array}{c}\text { Number of } \\
\text { lectures per } \\
\text { week }\end{array}$ & $\begin{array}{c}\text { Number of } \\
\text { seminars(workshops) } \\
\text { per week }\end{array}$ & Credits(ECTS) \\
\hline Annual project & 0 & 4 & 6 \\
Fundamentals of Mercantile and Financial Law & 2 & 0 & 2 \\
Tax system & 2 & 0 & 3 \\
Financial management & 3 & 2 & 7 \\
Financial and economic analysis of the technol. & 3 & 2 & 7 \\
\hline
\end{tabular}

Table 7. The fourth semester

\begin{tabular}{lccc}
\hline \multicolumn{1}{c}{ The subject } & $\begin{array}{c}\text { Number of } \\
\text { lectures per } \\
\text { week }\end{array}$ & $\begin{array}{c}\text { Number of } \\
\text { seminars(workshops) } \\
\text { per week }\end{array}$ & Credits(ECTS) \\
\hline Diploma thesis work & 0 & 18 & 24 \\
Ethics and Etiquette in Managerial Activity & 1 & 0 & 1 \\
Management of Small and Medium sized & 2 & 0 & 3 \\
Enterprises & & 0 & 2 \\
Fundamentals of Industrial Law & 2 & 0 & 2 \\
\hline
\end{tabular}

For successful completion of the study, the student must obtain 120 credits (as the ECTS standard for the second level of university studies) and defend the final diploma thesis.

\section{Conclusion}

The development of innovation is essential for economic and social future of Slovakia. Strong economic growth in 2000 - 2007 was driven by the global economic boom as well as specific competitive advantages of Slovakia, especially low-cost labour and low taxes. This competition method is not sustainable for Slovakia in the long term. Parameters of sustainability of economic development of the Slovak Republic are currently fundamentally changing. Competitiveness growth of Slovakia necessary requires a change of industrial structure of national economy towards innovative development. An important input factor in innovative performance of the economy is highly qualified personnel, including university graduates, especially in natural science and engineering. An important issue in 
the present situation of the knowledge-based economy in Slovakia is also the increase of knowledge productivity and lifelong education of workers.

The innovative direction of development of the Slovak economy in the processes of human capital forming is dominated by universities ensuring preparation of the national professional elite. The main role of universities becomes the preparation of highly professional experts needed for implementation of perspective scientific researches and the transfer of their results into practical use. Universities, responding to the challenges of the innovation economy in the area of personnel training, must be able to successfully handle the following tasks:

- Teach students to independently seek necessary information, to perform its critical analysis and to acquire new knowledge;

- Provide habits for the practical use of acquired knowledge, allowing to adapt to the conditions of competition in the labour market in real economic environment;

- Provide programme to acquire additional qualification enabling graduates to become competitive in the new innovative environment at various stages of their career.

The result of the above is that it is necessary to streamline the university system, so that high quality universities get significantly higher financial benefits. The goal is to:

-increase the quality of university education,

-increase the quality of university science and research,

-select elite universities with worldwide reputation,

- support cooperation with practice,

-commercialize results of research and development activities.

STU in Bratislava currently activates its activity in processes of building the intellectual capital in the form of research and education, ensuring economic competitiveness of the country. Active participation of STU in international and national research and development programs of innovation development increases its potential, which is the base element of the national innovation system.

\section{Acknowledgements}

This publication has been prepared as a partial output in the research project ref. no.: 1/0055/13, VEGA No. 13 Commission for Economic and Legal Sciences - Project title: Systemization impact factors and conditions of knowledge management in the context of business strategy on work motivation and its reflection in growth of efficiency, respectively sustainable levels of business.

\section{References}

1. European Commission, Education and Training Monitor 2014. Slovakia. Retrieved from: http://ec.europa.eu/education/tools/docs/2014/monitor2014-sk_en.pdf, (2014).

2. European Commission, Press release 13-324. Retrieved from: http://europa.eu/rapid/press-release_IP-13-324_sk.htm, (2013).

3. Ivanička, K. et al., Trvalá udržatel’nost' inovácií v rozvoji Slovenska (Permanent sustainability of innovations in the development of Slovakia). Publisher Wolters Kluwer, s.r.o., 309 p., ISBN 978-80-8168-036-6, (2014).

4. OECD, Education at a Glance 2014: OECD Indicators. OECD Publishing. http://dx.doi.org/10.1787/eag-2014-en, (2014). 
5. Schwab K., The Global Competitiveness Report 2014-2015. Switzerland. Retrievedfrom:http://www3.weforum.org/docs/WEF_GlobalCompetitivenessReport_2 014-15.pdf, (2014). 